\title{
Spectrophotometric Determination of Tellurium (IV) with Chrome Azurol S: Application to Sea Water and Synthetic Alloys
}

\author{
Sadallah T. Sulaiman \\ Ghaida K. Hanna \\ Department of Chemistry \\ College of Science \\ University of Mosul
}

\author{
Wadala A. Bashir
}

(Received 9/10/2012 ; Accepted 17/12/2012)

\begin{abstract}
The detailed investigation of a sensitive spectrophotometric method for the determination of trace amounts of tellurium (IV) is described. The method is based on the reaction of tellurium (IV) with chrome azurol $\mathrm{S}$ in the presence of cetylpyridinium chloride hydrate surfactant at a final $\mathrm{pH}$ of 3.1 to form a pink coloured chelate absorbing maximum at $525 \mathrm{~nm}$. Beer's law is obeyed over the range (5-50) $\mu \mathrm{g} / 25 \mathrm{ml}$, with a molar absorptivity of $\left(2.5 \times 10^{4}\right) 1 . \mathrm{mol}^{-1} \cdot \mathrm{cm}^{-1}$ and a coefficient of determination $\left(\mathrm{r}^{2}\right)$ of 0.9997 . Sandell's sensitivity index is $\left(5.104 \times 10^{-3}\right) \mu \mathrm{g} . \mathrm{cm}^{-2}$, a relative error of $(0.8-0.2 \%)$ and a relative standard deviation of $(0.2$ to \pm 1.8$) \%$, depending on the concentration levels in the calibration curve. The method has been applied successfully to determine Te (IV) in sea water and some synthetic alloys.
\end{abstract}

Keywords: Te (IV) determination, Chrome azurol $\mathrm{S}$ reagent, Cetyl pyridinium chloride hydrate, Spectrophotometry.

\section{القير لاليفي التيليريو الرياعي بكلثف Chrome Azurol S - التلبق علدماء البحر والسباك المصنهة}

\section{ll}

م طوويرطريقةطيفية هسلسة لقديركميت متناهية في الصغرمن ايون التيليريوم الرباعي مع كلثف بوجود Chrome Azurol S مخلبي وردي في الوسط المائي الذي يطي اعلى امتصاص عند الطول الموجي525 نانوميتر. وكافت حدود قانون بير في مدى التركيز (50-50) مايكروغرام في حهم الفاعل النهائي 25 مللتر وكانت الامتصاصية

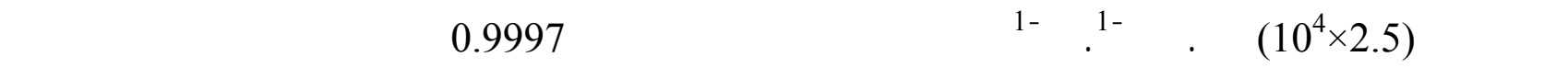

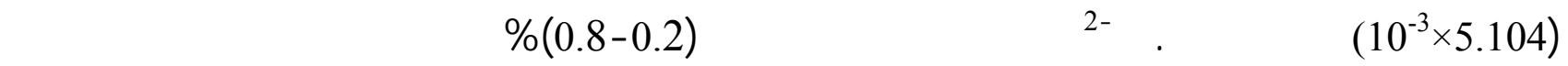

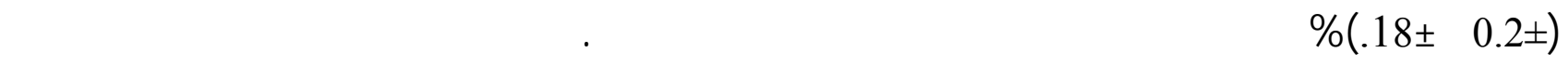
الرباعي في بعض اللسبائك المصنعة وماء البحر . 


\section{INTRODUCTION}

Tellurium came from the Latin word tellus that means earth, it can be found in dioxide form, the properties of tellurium included a silvery-gray colour, boiling point of $1810^{\circ} \mathrm{F}$, melting point of $841.12^{\circ} \mathrm{F}$. In air, tellurium burns in a greenish-blue flame forming the dioxide, $\mathrm{TeO}_{2}$ is highly insoluble in water and soluble in concentrated sulfuric acid. It reacts with acids to make tellurium salts and bases to make tellurites (Mediawlki, 2012).

Tellurium's conductivity can also increase if exposed to light. Tellurium can be used in ceramics. It can be added to lead to prevent corrosion and strength (Whinnie,1994).

The impact of tellurium supply on cadmium telluride photovoltaics modules have become the lowest-cost producer of solar electricity, despite working at lower efficiency than crystalline silicon cell (Ken, 2010).

A spectrophotometric method for the determination of palladium, iron and tellurium from nitric acid media after the extraction of their p-[4-(3,5-dimethyl soxazol-yl) azophenylazo]calyx(4) arene complexes has been developed with possible synergistic effects (Kumar et al., 2008)

Atomic absorption spectrometric determination of trace tellurium after hydride trapping on platinum-coated tungsten coil has been worked out. This method was applied to the determination of tellurium in several geological standard reference materials, by hyphenation of electrically heated quartz tube atomic absorption spectrometry and tellurium hydride trapping on platinum-coated tungsten coil. With a mixture of $\mathrm{Ar}$ and $\mathrm{H}_{2}$, tellurium hydride was transported to tungsten coil for trapping at $390^{\circ} \mathrm{C}$ and releasing at $1200^{\circ} \mathrm{C}$ (Maoyang et al., 2010).

$\mathrm{Te}$ (IV) and $\mathrm{Te}$ (VI) were determined by employing dispersive liquid-liquid microextraction combined with electrothermal atomic absorption spectrometry using palladium as a permanent modifier. Under acidic condition ( $\mathrm{pH} 1$ ), only Te (IV) formed a complex with ammonium pyrrolidine dithiocarbamate (APDC) and therefore Te (IV) was determined in the sedimented organic phase while Te (VI) remained in the aqueous phase (Najafi, et al., 2010).

Determination of bismuth, selenium and tellurium in nickel-based alloys and pure copper by flow-injection hydride generation atomic absorption spectrometry with ascorbic acid prereoduction and cupferron chelation extraction was performed in phosphate buffer. For $\mathrm{H}_{2} \mathrm{Te}$, the linear range for the calibration curve was $0.5-12 \mathrm{ng} / \mathrm{ml}$ (Hui-Ming et al., 2002).

The reagent used in this investigation chrome azurol S (CAS) is trisodium salt of sulphodichlorohydroxy dimethyl fuchson dicarboxylic acid. The structural formula of the reagent is: 
<smiles>CC1=CC(=C(c2cc(C)c(O)c(C(=O)O[Na])c2)c2c(Cl)ccc(S(=O)(=O)O[Na])c2Cl)C=C(C(=O)O[Na])C1=O</smiles>

Chrome Azurol S (MW $=605.28 \mathrm{~g} / \mathrm{mole})$

The above reagent has been used to determine indium (Poledniok and Buhl, 2006), vanadium (IV) (Starczewska, 2004) and cobalt (Mushran et al., 2004) as ternary (in the presence of surfactant) or as binary complexes.

The present study involves the determination of Te (IV) using the reagent CAS. To the best of our knowledge, such investigation has not yet been touched.

\section{Apparatus}

\section{EXPERIMENTAL}

Spectral and absorbance measurements were carried out using CECIL CE7200 Aquarius spectrophotometer with 1-cm matched quartz cells.

The $\mathrm{pH}$ measurements were carried out using professional Beuchtop pH meter Bp3001.

\section{Reagents}

All chemicals used were of analytical reagent grade.

\section{Stock Tellurium (IV) $(100 \mu \mathrm{g} / \mathrm{ml})$ solution.}

This solution was prepared by dissolving $0.0125 \mathrm{~g}$ of tellurium dioxide (Hopkin and Williams) in $2 \mathrm{ml}$ concentrated $\mathrm{HCl}$ solution and the volume was completed to $100-\mathrm{ml}$ with distilled water in a volumetric flask.

\section{Working Tellurium (IV) $(50 \mu \mathrm{g} / \mathrm{ml})$ solution.}

This solution was prepared by diluting $50 \mathrm{ml}$ of the above stock tellurium (IV) solution to 100 $\mathrm{ml}$ with distilled water in a volumetric flask.

\section{Chrome Azurol S (CAS) reagent $\left(1 \times 10^{-4} M\right)$ solution.}

It was prepared by dissolving $0.00605 \mathrm{~g}$ of Chrome Azurol S (Merck) in distilled water and the solution is diluted to $100 \mathrm{ml}$ in a volumetric flask and then transferred to a dark bottle, where it was stable for at least seven days.

\section{Buffer solution (pH10)}

This solution was prepared by mixing $17.41 \mathrm{ml}$ of $0.02 \mathrm{M}$ sodium bicarbonate solution and $21.89 \mathrm{ml}$ of $0.01 \mathrm{M}$ sodium carbonate and the volume was diluted to $100 \mathrm{ml}$ with distilled water in a volumetric flask (Perrin and Dempsey, 1974).

\section{Cetylpyridinium chloride hydrate $(\mathrm{CPC})\left(1 \times 10^{-3} \mathrm{M}\right)$ solution}

This solution was prepared by dissolving $0.0358 \mathrm{~g}$ of cetylpyridinium chloride hydrate $(\mathrm{CPC})(\mathrm{BDH})$ in distilled water and the volume was completed to $100 \mathrm{ml}$ in a volumetric flask. 


\section{Interfering ion solutions.}

A $100 \mu \mathrm{g} / \mathrm{ml}$ solution of each ion tested was prepared in distilled water.

\section{Synthetic sea water.}

It was prepared as described (Herkinson, 1965) by dissolving $2.2 \mathrm{~g} \mathrm{NaCl}, 9.7 \mathrm{~g}$ $\mathrm{MgCl}_{2} .6 \mathrm{H}_{2} \mathrm{O}, 3.7 \mathrm{~g} \mathrm{Na}_{2} \mathrm{SO}_{4}, 1 \mathrm{~g} \mathrm{CaCl}_{2}, 0.65 \mathrm{~g} \mathrm{KCl}, 0.17 \mathrm{~g} \mathrm{NaHCO}_{3}$ and $0.023 \mathrm{~g} \mathrm{H}_{3} \mathrm{BO}_{3}$ in about $500 \mathrm{ml}$ of distilled water, then the solution was diluted to 11 with distilled water in a volumetric flask.

\section{Preliminary Investigations}

\section{RESULTS AND DISCUSSION}

For subsequent investigations, $50 \mu \mathrm{g}$ of Te (IV) were taken in a $25 \mathrm{ml}$ final volumes. Upon the addition of CAS reagent to Te (IV) solution, an orange-red species was formed against the corresponding yellow blank solution.

\section{Optimization of Experimental Conditions}

The effect of various factors that may affect the analytical characteristics of the coloured species has been investigated and optimal experimental conditions are selected.

\section{Effect of pH}

The effect of $\mathrm{pH}$ of the final reaction solutions is studied by adding different volumes of (0.01) $\mathrm{M} \mathrm{HCl}$ or $\mathrm{NaOH}$ to the mixture containing $50 \mu \mathrm{g}$ of tellurium (IV) and $5 \mathrm{ml}$ of $1 \times 10^{-4} M$ CAS. The spectrum was scanned for each coloured solution against its corresponding reagent blank, blank against distilled water and the final $\mathrm{pH}$ was measured. The results obtained were given in Table (1).

Table 1: Effect of pH on the absorbance of Te solution

\begin{tabular}{|c|c|c|c|c|c|c|c|c|c|}
\hline \multirow{3}{*}{$\begin{array}{c}\text { ml of acid or base } \\
(0.01 \text { M) solution } \\
\text { added }\end{array}$} & \multicolumn{9}{|c|}{ Absorbance / electrolyte added } \\
\hline & \multicolumn{4}{|c|}{ HCl } & \multicolumn{5}{|c|}{$\mathrm{NaOH}$} \\
\hline & $\mathrm{A}_{\mathrm{B}}^{\mathrm{S}}$ & $\lambda_{\max }, \mathrm{nm}$ & $\mathrm{A}^{\mathrm{B}}{ }_{\mathrm{w}}$ & $\mathrm{pH}$ & $\mathrm{A}_{\mathrm{B}}^{\mathrm{S}}$ & $\begin{array}{c}\lambda_{\max }, \\
\mathrm{nm}\end{array}$ & $\mathrm{A}_{\mathrm{w}}^{\mathrm{B}}$ & $\begin{array}{c}\lambda_{\max } \\
\mathrm{nm}\end{array}$ & $\mathrm{pH}$ \\
\hline 0.0 & 0.073 & 486.9 & 0.248 & 2.4 & 0.073 & 486.9 & 0.248 & 434 & 2.49 \\
\hline 1 & 0.006 & - & 0.123 & 2.47 & 0.151 & 487.1 & 0.271 & 431 & 2.50 \\
\hline 3 & -0.001 & - & 0.121 & 2.40 & 0.173 & 501 & 0.286 & 425.3 & 2.53 \\
\hline 4 & -0.001 & - & 0.118 & - & 0.180 & 501 & 0.292 & 425.3 & 2.59 \\
\hline 5 & -0.010 & - & 0.123 & - & 0.192 & 501.5 & 0.275 & 425.3 & 2.6 \\
\hline 7 & -0.017 & - & 0.127 & - & 0.201 & 502 & 0.266 & 425.3 & 2.69 \\
\hline 8 & - & - & - & - & 0.208 & 502 & 0.264 & 425.3 & 2.81 \\
\hline 9 & - & - & - & - & 0.220 & 502.5 & 0.264 & 425.3 & 2.86 \\
\hline 10 & - & - & - & - & 0.294 & 505.3 & 0.257 & 425.3 & 2.96 \\
\hline 11 & - & - & - & - & 0.300 & 505 & 0.227 & 425.3 & 3.1 \\
\hline 12 & - & & - & - & 0.294 & 502.5 & 0.219 & 425.3 & 3.25 \\
\hline 13 & - & & - & - & 0.290 & 500 & 0.210 & 425.3 & 3.48 \\
\hline 14 & - & & - & - & 0.273 & 497 & 0.204 & 425.3 & 4.07 \\
\hline 15 & - & & - & - & 0.065 & 424.1 & 0.200 & 425.3 & 9.35 \\
\hline
\end{tabular}


From the results in Table (1), it can be shown that $\mathrm{pH}$ values (2.96-3.48) were favorable for the formation of the coloured compound. Furthermore, the wavelengths of maximum absorption of both standard and blank were constant. The $\mathrm{pH}$ was 3.1 although 11 $\mathrm{ml}$ of $0.01 \mathrm{M} \mathrm{NaOH}$ solution was added because the element was originally dissolved in some strong acid medium.

At the optimum amount of $\mathrm{NaOH}(11 \mathrm{ml}$ of $0.01 \mathrm{M})$ solution, buffers of $\mathrm{pH} 10$ (sodium carbonate + sodium bicarbonate) and pH12 (NaOH, $\mathrm{KCl}$ buffer) (Perrin and Dempsey, 1974) have been tried. $\mathrm{pH} 10$ gives more useful results than $\mathrm{pH} 12$ and, therefore, were incorporated in the subsequent experiments. Also, $\mathrm{pH} 10$ gave more useful results in terms of colour contrast while $\mathrm{NaOH}$ solution gave lower blank value. The experimental results were represented in Table (2).

Table 2: Effect of buffers on absorbance

\begin{tabular}{|c|c|c|c|c|c|c|c|}
\hline \multirow{3}{*}{$\begin{array}{c}\text { mL of } \\
\text { buffer } \\
\text { solution }\end{array}$} & \multicolumn{7}{|c|}{ Absorbance / mL of buffer added } \\
\hline & \multicolumn{3}{|c|}{ pH10 at $\lambda 515 \mathrm{~nm}^{*}$} & \multicolumn{4}{|c|}{ pH12 } \\
\hline & $\mathrm{A}_{\mathrm{B}}^{\mathrm{S}}$ & $\mathbf{A}_{\mathbf{W}}^{\mathbf{B}}$ & $\mathrm{pH}_{\text {formation }}$ & $\mathbf{A}_{\mathbf{B}}^{\mathbf{S}}$ & $\mathbf{A}^{\mathbf{B}}{ }_{\mathbf{w}}$ & $\lambda \mathbf{n m}$ & $\mathbf{p H}_{\text {formation }}$ \\
\hline 1 & 0.087 & 0.038 & 2.88 & 0.195 & 0.039 & 519 & 2.67 \\
\hline 2 & 0.098 & 0.039 & 3.01 & 0.208 & 0.041 & 516 & 2.72 \\
\hline 3 & 0.100 & 0.040 & 3.06 & 0.204 & 0.044 & 516 & 2.88 \\
\hline 4 & 0.122 & 0.042 & 3.09 & 0.197 & 0.050 & 516 & 3.13 \\
\hline 5 & 0.155 & 0.044 & 3.10 & 0.057 & 0.050 & 495 & 5.80 \\
\hline 6 & 0.193 & 0.045 & 3.15 & 0.015 & 0.055 & 448 & 9.48 \\
\hline 7 & 0.181 & 0.046 & 3.32 & 0.011 & 0.056 & 432 & 10.74 \\
\hline 8 & 0.169 & 0.046 & 4.53 & 0.009 & 0.062 & 422 & 11.98 \\
\hline 9 & 0.153 & 0.047 & 5.15 & 0.007 & 0.074 & 420 & 11.05 \\
\hline 10 & 0.148 & 0.047 & 6.09 & 0.005 & 0.150 & 420 & 11.14 \\
\hline 11 & 0.140 & 0.048 & 6.52 & \multicolumn{4}{|c|}{ Turbid } \\
\hline 12 & 0.109 & 0.048 & 6.60 & \multicolumn{4}{|c|}{ Turbid } \\
\hline 13 & 0.083 & 0.052 & 6.83 & \multicolumn{4}{|c|}{ Turbid } \\
\hline
\end{tabular}

*With buffers, $\lambda_{\max }$ shifts from $506 \mathrm{~nm}$ to $515 \mathrm{~nm}$ a bicarbonate carbonate buffer.

According to the results in Table 2, $6 \mathrm{ml}$ of $\mathrm{pH} 10$ buffer solution was chosen for the subsequent work, since it gave a good absorbance for the standard and lower blank value.

For the final $\mathrm{pH}$ of 3.1, $\mathrm{pH} 10$ and $\mathrm{pH} 12$ have been selected for the examination. These higher $\mathrm{pH}$ values buffers were chosen because the Te element was initially dissolved in acid solution (see experimental). The effect of the amount of buffer solutions on the absorbance of the final coloured solutions was shown in Table (2).

Effect of Reagent Amount and The Concentration of Tellurium (IV)

The formation of the coloured complex has been completed using $7 \mathrm{ml}$ of $1 \times 10^{-4} \mathrm{M}$ CAS, the results were shown in Table (3).

Table 3: Effect of the reagent amount and concentration of tellurium

\begin{tabular}{|c|c|c|c|c|c|c|c|}
\hline \multirow[t]{2}{*}{ ML of CAS reagent } & \multicolumn{6}{|c|}{ Absorbance / $\mu \mathrm{g}$ of Tellurium added } & \multirow[b]{2}{*}{$\mathbf{R}^{2}$} \\
\hline & 5 & 25 & 40 & 50 & $75^{*}$ & $100 *$ & \\
\hline 1 & 0.011 & 0.050 & 0.075 & 0.093 & 0.078 & 0.050 & 0.9988 \\
\hline 3 & 0.017 & 0.125 & 0.173 & 0.205 & 0.185 & 0.163 & 0.9803 \\
\hline 5 & 0.025 & 0.135 & 0.204 & 0.245 & 0.191 & 0.111 & 0.9960 \\
\hline 7 & 0.045 & 0.130 & 0.191 & 0.230 & 0.205 & 0.190 & 0.9997 \\
\hline 9 & 0.012 & 0.144 & 0.245 & 0.295 & 0.179 & 0.156 & 0.9955 \\
\hline
\end{tabular}

*75 $\mu \mathrm{g}$ and $100 \mu \mathrm{g}$ were not considered when calculating $\mathrm{R}^{2}$ 
The coefficient of determination correlates that $7 \mathrm{ml}$ of $1 \times 10^{-4} M$ CAS was the optimum amount for the determination of (5-50) $\mu \mathrm{g}$ Te (IV) ion.

\section{Effect of Surfactants}

The effect of different types of surfactants (cationic, anionic and non-ionic) with different concentrations on the intensity of the coloured complex with different orders of addition has been examined and the results were shown in Table (4).

\section{Table 4: Effect of surfactant amounts}

\begin{tabular}{|c|c|c|c|c|c|c|c|c|c|c|}
\hline \multirow{2}{*}{$\begin{array}{c}\text { Surfactant } \\
\text { solution used }\end{array}$} & \multirow{2}{*}{\multicolumn{2}{|c|}{ Order Variable }} & \multicolumn{8}{|c|}{ Absorbance $* / \mathrm{ml}$ of surfactant solution } \\
\hline & & & 0.0 & 1.0 & 2 & 3 & 4 & 5 & $\lambda_{\max } \mathrm{nm}$ & pH \\
\hline \multirow{6}{*}{$\begin{array}{l}\text { CTAB } \\
\left(1 \times 10^{-3} \mathrm{M}\right)\end{array}$} & & $\mathbf{A}_{\mathbf{B}}^{\mathbf{S}}$ & 0.269 & 0.350 & 0.376 & 0.372 & 0.365 & 0.360 & \multirow{6}{*}{524.5} & \multirow{6}{*}{3.02} \\
\hline & I & $\mathbf{A}_{\mathbf{w}}^{\mathbf{B}}$ & 0.070 & 0.055 & 0.052 & 0.050 & 0.050 & 0.050 & & \\
\hline & II & $\mathbf{A}_{B}^{\mathbf{S}_{B}}$ & 0.269 & 0.315 & 0.320 & 0.327 & 0.315 & 0.310 & & \\
\hline & & $\mathbf{A}_{w}^{\mathbf{B}}$ & 0.070 & 0.055 & 0.052 & 0.050 & 0.050 & 0.050 & & \\
\hline & \multirow{2}{*}{ III } & $\mathbf{A}_{B}^{\mathbf{S}}$ & 0.269 & 0.311 & 0.143 & 0.069 & 0.065 & 0.063 & & \\
\hline & & $\mathbf{A}_{w}^{\mathbf{B}}$ & 0.065 & 0.052 & 0.050 & 0.050 & 0.050 & 0.050 & & \\
\hline \multirow{6}{*}{$\begin{array}{l}\text { CPC } \\
\left(1 \times 10^{-3} \mathrm{M}\right)\end{array}$} & \multirow{2}{*}{ I } & $\mathbf{A}_{B}{ }_{B}$ & 0.269 & 0.380 & 0.376 & 0.365 & 0.360 & 0.359 & \multirow{6}{*}{525} & \multirow{6}{*}{3.14} \\
\hline & & $\mathbf{A}^{\mathbf{B}}{ }_{w}$ & 0.070 & 0.044 & 0.032 & 0.026 & 0.025 & 0.025 & & \\
\hline & \multirow{2}{*}{ II } & $\mathbf{A}_{\mathbf{B}}^{\mathbf{S}_{1}}$ & 0.269 & 0.382 & 0.380 & 0.370 & 0.358 & 0.356 & & \\
\hline & & $\mathbf{A}_{w}^{\mathbf{B}}$ & 0.070 & 0.040 & 0.035 & 0.028 & 0.025 & 0.025 & & \\
\hline & \multirow[t]{2}{*}{ III } & $\mathbf{A}_{\text {B }}^{\mathbf{S}_{1}}$ & 0.269 & 0.395 & 0.380 & 0.360 & 0.358 & 0.357 & & \\
\hline & & $\mathbf{A}^{\mathbf{B}}{ }_{w}$ & 0.070 & 0.037 & 0.035 & 0.028 & 0.025 & 0.025 & & \\
\hline \multirow{6}{*}{$\begin{array}{l}\text { SDS } \\
\left(1 \times 10^{-3} \mathrm{M}\right)\end{array}$} & \multirow{2}{*}{ I } & $\mathbf{A}_{B}^{S_{B}}$ & 0.269 & 0.247 & 0.253 & 0.258 & 0.253 & 0.245 & \multirow{6}{*}{511} & \multirow{6}{*}{3.21} \\
\hline & & $\mathbf{A}_{w}^{\mathbf{B}}$ & 0.070 & 0.060 & 0.052 & 0.051 & 0.049 & 0.049 & & \\
\hline & \multirow{2}{*}{ II } & $\mathbf{A}_{B}^{S_{B}}$ & 0.269 & 0.235 & 0.280 & 0.295 & 0.297 & 0.286 & & \\
\hline & & $\mathbf{A}^{\mathbf{B}}{ }_{w}$ & 0.070 & 0.055 & 0.052 & 0.052 & 0.052 & 0.050 & & \\
\hline & \multirow{2}{*}{ III } & $\mathbf{A}_{\text {B }}^{\mathbf{S}_{1}}$ & 0.269 & 0.291 & 0.298 & 0.310 & 0.312 & 0.304 & & \\
\hline & & $\mathbf{A}_{w}^{\mathbf{B}}$ & 0.070 & 0.055 & 0.054 & 0.052 & 0.050 & 0.049 & & \\
\hline \multirow{6}{*}{$\begin{array}{l}\text { TritonX- } \\
100(1 \%)\end{array}$} & & $\mathbf{A}_{\mathbf{B}}^{\mathbf{S}}$ & 0.269 & 0.220 & 0.233 & 0.258 & 0.240 & 0.231 & \multirow{6}{*}{504.5} & \multirow{6}{*}{3.64} \\
\hline & I & $\mathbf{A}_{{ }_{w}}^{\mathbf{B}}$ & 0.070 & 0.051 & 0.049 & 0.049 & 0.048 & 0.048 & & \\
\hline & \multirow{2}{*}{ II } & $\mathbf{A}_{B}^{\mathbf{S}}$ & 0.269 & 0.239 & 0.23 & 0.225 & 0.220 & 0.219 & & \\
\hline & & $\mathbf{A}_{w}^{\mathbf{B}}$ & 0.070 & 0.050 & 0.049 & 0.048 & 0.047 & 0.047 & & \\
\hline & \multirow{2}{*}{ III } & $\mathbf{A}_{\text {B }}^{\mathbf{S}}$ & 0.269 & 0.230 & 0.228 & 0.226 & 0.223 & & & \\
\hline & & $\mathbf{A}_{w}^{\mathbf{B}}$ & 0.070 & 0.050 & 0.050 & 0.050 & 0.050 & & & \\
\hline
\end{tabular}

$\lambda_{\max }=515 \mathrm{~nm}$ 


\section{Order number I: (M+B+R+S), II: (M+B+S+R), III: $(\mathbf{M}+\mathbf{S}+\mathbf{B}+\mathbf{R})$}

The results shown in Table (4) show that the maximum absorbance has been achieved using $1 \mathrm{ml}$ of $1 \times 10^{-3} \mathrm{M}$ cetylpyridinium chloride hydrate (CPC) with the order (tellurium (IV) ion $+\mathrm{CPC}+\mathrm{pH} 10+\mathrm{CAS}$ reagent $)$.

The presence of CPC surfactant afforded both hyperchromic effect and bathochromic shift (515 nm to $525 \mathrm{~nm})$ which are both admired from the analytical point of view.

\section{Effect of time and CPC Surfactant}

The effect of time on the colour intensity of the Te (IV)-CAS chelate produced from different amounts of tellurium (IV) ion has been explored. The maximum formation of the coloured complex took place after $5 \mathrm{~min}$, and remained stable for about $60 \mathrm{~min}$ at least in the presence of CPC, while in the absence of CPC lower absorbencies were observed and less efficient stability was attained. The results are shown in Table (5)

Table 5: Effect of time and CPC surfactant on absorbance and stability

\begin{tabular}{|c|c|c|c|c|c|c|c|c|}
\hline \multirow{3}{*}{$\begin{array}{l}\text { Time } \\
\text { Min. }\end{array}$} & \multicolumn{8}{|c|}{ Absorbance / $\mu \mathrm{g}$ Te (IV) added } \\
\hline & \multicolumn{4}{|c|}{ CPC absent } & \multicolumn{4}{|c|}{ CPC present } \\
\hline & 5 & 25 & 40 & 50 & 5 & 25 & 40 & 50 \\
\hline 5 & 0.012 & 0.128 & 0.188 & 0.220 & 0.025 & 0.345 & 0.365 & 0.378 \\
\hline 10 & 0.014 & 0.125 & 0.194 & 0.220 & 0.026 & 0.340 & 0.362 & 0.375 \\
\hline 20 & 0.016 & 0.125 & 0.194 & 0.210 & 0.026 & 0.315 & 0.362 & 0.370 \\
\hline 30 & 0.015 & 0.124 & 0.194 & 0.208 & 0.026 & 0.314 & 0.362 & 0.370 \\
\hline 40 & 0.015 & 0.124 & 0.194 & 0.208 & 0.026 & 0.314 & 0.362 & 0.370 \\
\hline 50 & 0.015 & 0.124 & 0.186 & 0.208 & 0.026 & 0.314 & 0.362 & 0.370 \\
\hline 60 & 0.015 & 0.12 & 0.186 & 0.205 & 0.025 & 0.314 & 0.362 & 0.370 \\
\hline
\end{tabular}

\section{Final Absorption Spectra}

The absorption spectra have been obtained on solution containing $50 \mu \mathrm{g}$ Te (IV), $1 \mathrm{ml}$ of $1 \times 10^{-3} \mathrm{M} \mathrm{CPC}, 6 \mathrm{ml} \mathrm{pH} 10,7 \mathrm{ml}$ of $1 \times 10^{-4} \mathrm{M} \mathrm{CAS}$, and the absorption spectra of the coloured complex are shown in Fig. 1 at $525 \mathrm{~nm}$, while the reagent blank gives maximum absorption at $423 \mathrm{~nm}$.

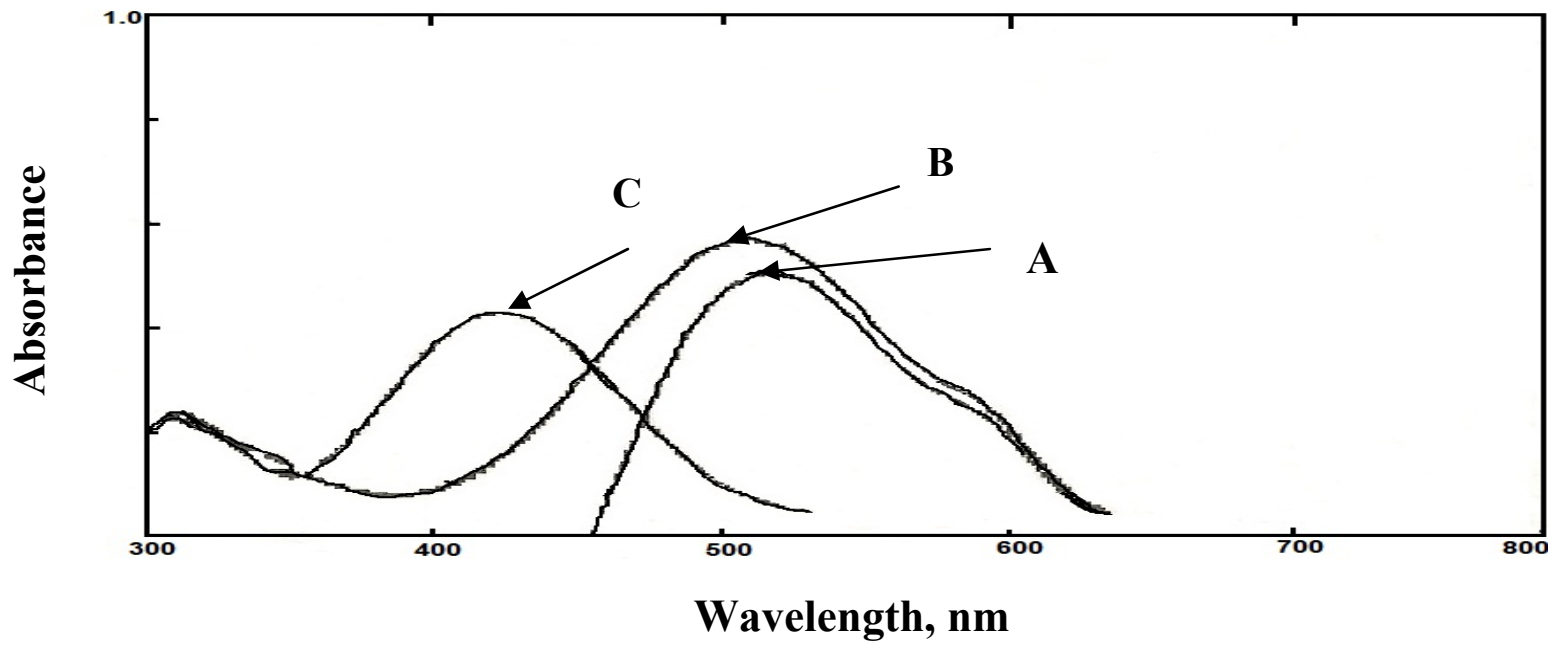

Fig. 1: Absorption spectra of $50 \mu \mathrm{g}$ Te (IV) treated as under optimum experimental conditions and measured (A): against blank, (B): against distilled water and (C): blank measured against distilled water. 


\section{Recommended procedure and calibration graph}

Under the optimum established conditions, described before, a calibration graph has been constructed as follows: increasing volumes of $50 \mu \mathrm{g} / \mathrm{ml}$ solution were transferred into $25-\mathrm{ml}$ volumetric flasks to cover the range (5-75) $\mu \mathrm{g} / 25 \mathrm{ml}$. Beer's law was obeyed over the range of (5-50) $\mu \mathrm{g} \mathrm{Te}$ (IV) Fig. (2). The average molar absorptivity of the coloured complex was calculated from the calibration graph and found to be $\left(2.5 \times 10^{4}\right) 1 . \mathrm{mol}^{-1} \cdot \mathrm{cm}^{-1}$, Sandell's sensitivity was $\left(5.104 \times 10^{-3}\right)$, while the limit of detection (LOD) and the limit of quantization (LOQ) (Valcarcel, 2000) were found to be $\left(61.8 \times 10^{-3}\right) \mu \mathrm{g} / \mathrm{ml}$ and $\left(84.6 \times 10^{-3}\right)$ $\mu \mathrm{g} / \mathrm{ml},(\mathrm{n}=30)$ respectively. At higher concentrations $(>50 \mu \mathrm{g} / 25 \mathrm{ml})$ of $\mathrm{Te}(\mathrm{IV})$, a negative deviation was observed.

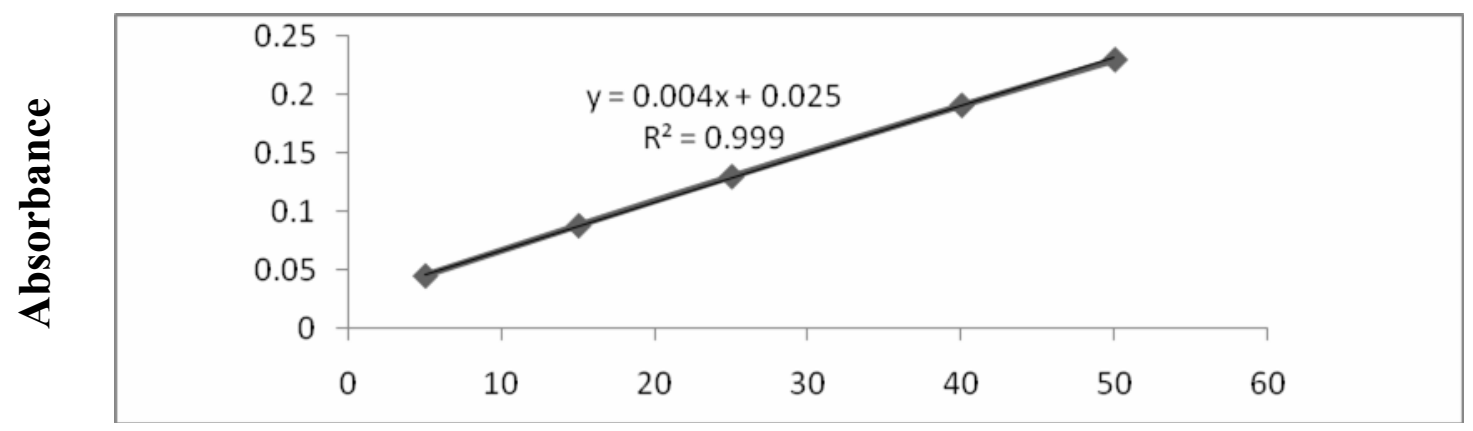

Concentration, $\mu \mathrm{g} / 25 \mathrm{ml}$

Fig. 2: Calibration graph for tellurium (IV) determination with chromeazurol S reagent.

\section{Accuracy and precision}

To check the accuracy and precision of the calibration graph, tellurium (IV) was determined at three different concentrations.

Table 6: Accuracy and Precision

\begin{tabular}{|l|l|l|}
\hline Te(IV) taken, $\boldsymbol{\mu g}$ & Recovery, \% * & $\begin{array}{l}\text { Relative Standard } \\
\text { Deviation, \% }\end{array}$ \\
\hline 25 & 98.2 & \pm 1.8 \\
\hline 40 & 100.2 & $\pm / 0.2$ \\
\hline 50 & 100.8 & \pm 0.8 \\
\hline
\end{tabular}

*For six determinations

The data given in Table 6 indicate that the results are satisfactory.

\section{Nature of the complex}

Job's method of continuous variations and mole-ratio method (Hargis, 1988) was used to evaluate the combining ratio between Te (IV) ion and CAS chelating agent. The results revealed that the ratio of tellurium (IV) to CAS is 1:2. Also, Job's method of continuous variations was used to determine the proportion of $\mathrm{CPC}$ in the complex. The results revealed that the components react in a ratio of 1: $4 \mathrm{Te}$ to $\mathrm{CPC}$. The structural formula of the chelate may be postulated as follows: 


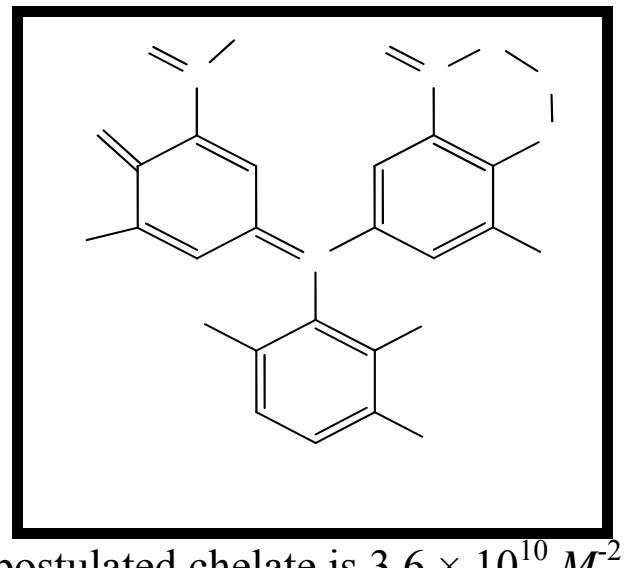

$\mathrm{O}$

The stability constant of the postulated chelate is $3.6 \times 10^{10} M^{-2}$.

\section{Effect of organic solvents}

Different organic solvents were used to examine their effects on the Te (IV)-CAS coloured complex. The results are shown in Table (7) and (Fig. 3). $\quad \mathrm{H}_{3} \mathrm{C}$

Table 7 : Effect of solvents on the optical properties of Te (IV) - CAS

\begin{tabular}{|c|c|c|c|c|}
\hline \multirow[t]{2}{*}{ Solvent } & \multicolumn{2}{|c|}{ Absorbance } & \multirow[t]{2}{*}{$\lambda, \max _{\mathrm{nm}}$} & \multirow[t]{2}{*}{$\varepsilon, 1 . \mathrm{mol}^{-1} \mathrm{~cm}^{-1}$} \\
\hline & $\mathrm{A}_{\mathrm{B}}^{\mathrm{S}}$ & $\mathbf{A}_{w}^{\mathbf{B}}$ & & \\
\hline Ethanol & \multicolumn{4}{|c|}{ Turbid } \\
\hline n-Propanol & 0.153 & 0.086 & 479 & $9.7 \times 10^{3}$ \\
\hline Formic acid & \multicolumn{4}{|c|}{ Turbid } \\
\hline Acetone & \multicolumn{4}{|c|}{ Turbid } \\
\hline DMF & 0.213 & 0.063 & 520 & $1.4 \times \mathrm{T}^{4}-$-Chrome \\
\hline Dioxane & 0.124 & 0.102 & 487 & $7.9 \times 10^{3}$ \\
\hline Tetrahydrofuran & 0.343 & 0.128 & 485 & $2.2 \times 10^{4}$ \\
\hline Water & 0.382 & 0.025 & 525 & $2.4 \times 10^{4}$ \\
\hline
\end{tabular}

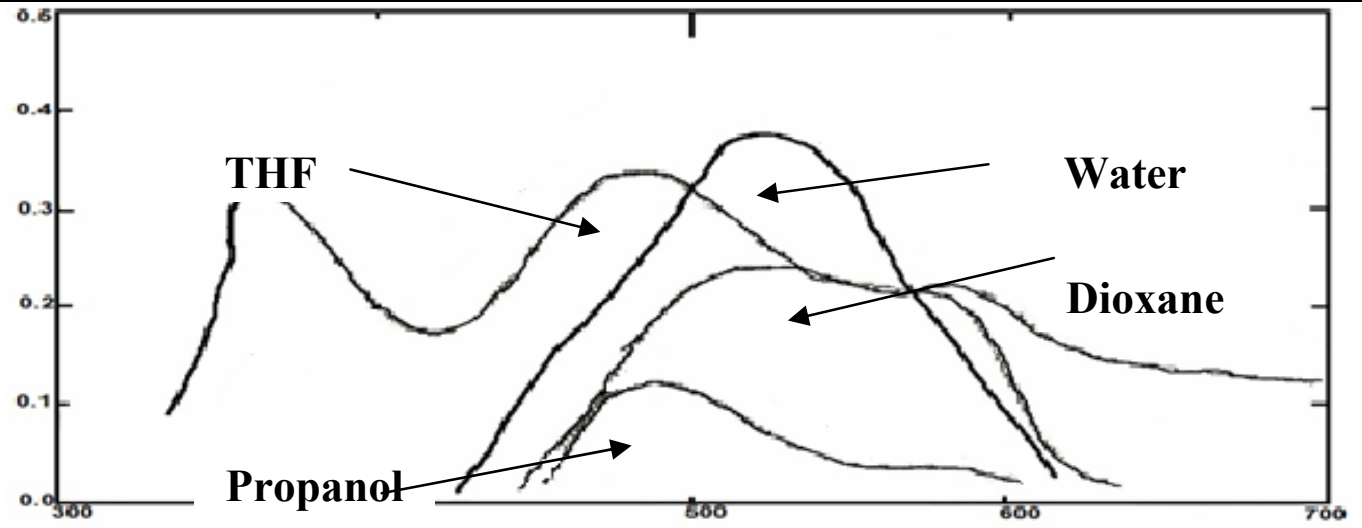

Fig. 3: Effect of organic solvents on the spectral properties of Te (IV) - CAS chelate.

As shown in Table (7), water seems to be still the most favorable solvent from the analytical point of view. 


\section{Study of interferences}

In order to assess the analytical applications of the proposed method, the effects of foreign ions were examined by adding known amounts of each foreign ion to a solution containing $50 \mu \mathrm{g}$ of tellurium (IV), and then determining the latter using the recommended procedure. The results obtained are summarized in Table (8).

\section{Table 8: Study of interference}

\begin{tabular}{|c|c|c|c|}
\hline Foreign ion & Form added & Amount added, $\mu \mathrm{g}$ & Interferences, \% \\
\hline \multirow{2}{*}{$\mathrm{Bi}^{3+}$} & \multirow{2}{*}{$\mathrm{Bi}\left(\mathrm{NO}_{3}\right)_{3} .5 \mathrm{H}_{2} \mathrm{O}$} & 50 & -9.7 \\
\hline & & 100 & -10.3 \\
\hline \multirow{2}{*}{$\mathrm{Pb}^{2+}$} & \multirow{2}{*}{$\mathrm{Pb}\left(\mathrm{NO}_{3}\right)_{2}$} & 50 & -12.9 \\
\hline & & 100 & -35.9 \\
\hline \multirow[t]{2}{*}{$\mathrm{Se}^{4+}$} & \multirow{2}{*}{$\mathrm{SeO}_{2}$} & 50 & -63.5 \\
\hline & & 100 & -64.9 \\
\hline \multirow[t]{2}{*}{$\mathrm{Ce}^{3+}$} & \multirow[t]{2}{*}{$\mathrm{CeCl}_{3} .7 \mathrm{H}_{2} \mathrm{O}$} & 50 & 0.0 \\
\hline & & 100 & 0.0 \\
\hline \multirow[t]{2}{*}{$\mathrm{Th}^{4+}$} & \multirow{2}{*}{$\mathrm{Th}\left(\mathrm{NO}_{3}\right)_{4} \cdot 6 \mathrm{H}_{2} \mathrm{O}$} & 50 & -47.0 \\
\hline & & 100 & -45.4 \\
\hline \multirow[t]{2}{*}{$\mathrm{Li}^{1+}$} & \multirow[t]{2}{*}{$\mathrm{Li}_{2} \mathrm{SO}_{4} \cdot \mathrm{H}_{2} \mathrm{O}$} & 50 & -0.3 \\
\hline & & 100 & -1.4 \\
\hline \multirow[t]{2}{*}{$\mathrm{Cd}^{2+}$} & \multirow[t]{2}{*}{$\mathrm{Cd}\left(\mathrm{CH}_{3} \mathrm{COO}\right)_{2} \cdot 2 \mathrm{H}_{2} \mathrm{O}$} & 50 & -6.2 \\
\hline & & 100 & -6.2 \\
\hline \multirow[t]{2}{*}{$\mathrm{Sr}^{2+}$} & $\mathrm{SrCl}_{2} \cdot 6 \mathrm{H}_{2} \mathrm{O}$ & 50 & 14.3 \\
\hline & & 100 & 14.7 \\
\hline $\mathrm{Ca}^{2+}$ & $\mathrm{CaCl}_{2}$ & 50 & +0.8 \\
\hline & & 100 & -3.5 \\
\hline $\mathrm{Na}^{1+}$ & $\mathrm{NaCl}$ & 50 & -2.2 \\
\hline & & 100 & -1.9 \\
\hline $\mathrm{Cu}^{2+}$ & $\mathrm{CuSO}_{4}$ & 50 & 10.0 \\
\hline & & 100 & 23.2 \\
\hline $\mathrm{Hg}^{2+}$ & $\mathrm{HgCl}_{2}$ & 50 & -4.3 \\
\hline & & 100 & -4.1 \\
\hline $\mathrm{V}^{5+}$ & $\mathrm{NH}_{4} \mathrm{VO}_{3}$ & 50 & +2.7 \\
\hline & & 100 & -10.8 \\
\hline $\mathrm{Al}^{3+}$ & $\mathrm{AlCl}_{3} .6 \mathrm{H}_{2} \mathrm{O}$ & 50 & +9.7 \\
\hline & & 100 & +15.9 \\
\hline $\mathrm{Ni}^{2+}$ & $\mathrm{NiCl}_{2} \cdot 6 \mathrm{H}_{2} \mathrm{O}$ & 50 & -0.9 \\
\hline & & 100 & +8.1 \\
\hline $\mathrm{Fe}^{3+}$ & $\mathrm{Fe}\left(\mathrm{NH}_{4}\right)\left(\mathrm{SO}_{4}\right)_{2} \cdot 6 \mathrm{H}_{2} \mathrm{O}$ & 50 & -2.9 \\
\hline & & 100 & -5.5 \\
\hline $\mathrm{Cr}^{3+}$ & $\mathrm{CrCl}_{3} .6 \mathrm{H}_{2} \mathrm{O}$ & 50 & -7.5 \\
\hline & & 100 & -4.2 \\
\hline $\mathrm{Sn}^{2+}$ & $\mathrm{SnCl}_{2} .2 \mathrm{H}_{2} \mathrm{O}$ & 50 & +0.9 \\
\hline & & 100 & -4.5 \\
\hline $\mathrm{Mn}^{2+}$ & $\mathrm{MnCl}_{2} \cdot 4 \mathrm{H}_{2} \mathrm{O}$ & 50 & -19.5 \\
\hline & & 100 & -18.8 \\
\hline $\mathrm{Mg}^{2+}$ & $\mathrm{MgSO}_{4} \cdot 7 \mathrm{H}_{2} \mathrm{O}$ & 50 & -2.3 \\
\hline & & 100 & -16.9 \\
\hline $\mathrm{W}^{6+}$ & $\mathrm{Na}_{2} \mathrm{WO}_{4} \cdot 2 \mathrm{H}_{2} \mathrm{O}$ & 50 & -3.2 \\
\hline & & 100 & +21.4 \\
\hline $\mathrm{Mo}^{6+}$ & $\left(\mathrm{NH}_{4}\right)_{6} \cdot \mathrm{Mo}_{7} \mathrm{O}_{24} \cdot 4 \mathrm{H}_{2} \mathrm{O}$ & 50 & -1.3 \\
\hline & & 100 & -25.1 \\
\hline $\mathrm{Ba}^{2+}$ & $\mathrm{BaCl}_{2} \cdot 2 \mathrm{H}_{2} \mathrm{O}$ & 50 & +8.5 \\
\hline & & 100 & +16.1 \\
\hline $\mathrm{S}_{2} \mathrm{O}_{3}^{2-}$ & $\mathrm{Na}_{2} \mathrm{~S}_{2} \mathrm{O}_{3} .5 \mathrm{H}_{2} \mathrm{O}$ & 50 & +3.0 \\
\hline & & 100 & +6.5 \\
\hline $\mathrm{HCO}_{3}{ }^{1-}$ & $\mathrm{NaHCO}_{3}$ & 50 & -3.1 \\
\hline & & 100 & +7.6 \\
\hline $\mathrm{CO}_{3}{ }^{2-}$ & $\mathrm{Na}_{2} \mathrm{CO}_{3}$ & 50 & -8.5 \\
\hline & & 100 & +10.8 \\
\hline $\mathrm{CrO}_{4}{ }^{2-}$ & $\mathrm{K}_{2} \mathrm{CrO}_{4}$ & 50 & +2.5 \\
\hline & & 100 & +5.8 \\
\hline $\mathrm{BO}_{3}^{3-}$ & $\mathrm{H}_{3} \mathrm{BO}_{3}$ & 50 & -1.2 \\
\hline & & 100 & +3.1 \\
\hline $\mathrm{Br}^{1-}$ & $\mathrm{KBr}$ & 50 & +0.4 \\
\hline & & 100 & +0.8 \\
\hline $\mathrm{SO}_{4}{ }^{2-}$ & $\mathrm{Na}_{2} \mathrm{SO}_{4}$ & 50 & -1.0 \\
\hline & & 100 & +0.9 \\
\hline $\mathrm{SCN}^{1-}$ & $\mathrm{KSCN}$ & 50 & +7.1 \\
\hline & & 100 & -10.3 \\
\hline $\mathrm{H}_{2} \mathrm{PO}_{4}{ }^{1-}$ & $\mathrm{NaH}_{2} \mathrm{PO}_{4} \cdot 2 \mathrm{H}_{2} \mathrm{O}$ & 50 & +1.3 \\
\hline & & 100 & +4.6 \\
\hline
\end{tabular}


The results in the above table indicate that a high negative and positive errors were observed in the case of $\mathrm{Al}$ (III), $\mathrm{Bi}$ (III), Th (IV), $\mathrm{Ba}$ (II), $\mathrm{Mn}$ (II), $\mathrm{Pb}$ (II), $\mathrm{Se}$ (IV), $\mathrm{Cu}$ (II), $\mathrm{SCN}^{-}$and $\mathrm{CO}_{3}\left(^{-} \mathrm{II}\right)$ due to the competition of these ions with $\mathrm{Te}$ (IV) for the reagent (appearance of blue colour) there by depleting the reagent available for the Te (IV) ion.

\section{Application of the method}

The method was applied to the determination of tellurium ion in synthetic composite mixture first and in sea water second. The results are listed below:

\section{Determination of tellurium (IV) in synthetic composite mixture}

Mixtures containing cations and anions and $50 \mu \mathrm{g}$ of tellurium (IV) were analyzed for tellurium. The results are given in Table (9).

Table 9: Recovery of Tellurium (IV) in synthetic mixture

\begin{tabular}{|c|c|c|c|}
\hline Ion added & $\begin{array}{l}\text { Mixture } \\
\text { numbers }\end{array}$ & Amount added, $\mu$ g mixture & Recovery, \% \\
\hline \multirow[t]{2}{*}{$\mathrm{Sn}^{+2}, \mathrm{Ce}^{+3}, \mathrm{Ni}^{+2}, \mathrm{SO}_{4}^{-2}, \mathrm{~S}_{2} \mathrm{O}_{3}^{-2}$} & \multirow[t]{2}{*}{ (I) } & 50 & 91.5 \\
\hline & & 100 & 104.5 \\
\hline \multirow{2}{*}{$\begin{array}{l}\mathrm{Ca}^{+2}, \mathrm{Mg}^{+2}, \mathrm{Ce}^{+3}, \mathrm{BO}_{3}^{-3}, \\
\mathrm{Br}^{-3}, \mathrm{SO}_{4}^{-2}\end{array}$} & \multirow[t]{2}{*}{ (II) } & 50 & 97.5 \\
\hline & & 100 & 131.6 \\
\hline \multirow{2}{*}{$\begin{array}{l}\mathrm{Ca}^{+2}, \mathrm{Mg}^{+2}, \mathrm{Ni}^{+2}, \mathrm{Bi}^{+3} \\
\mathrm{H}_{2} \mathbf{P O}_{4}^{-}, \mathrm{S}_{2} \mathrm{O}_{3}^{-2}\end{array}$} & \multirow[t]{2}{*}{ (III) } & 50 & 88.3 \\
\hline & & 100 & 88.0 \\
\hline \multirow{2}{*}{$\begin{array}{l}\mathrm{H}_{2} \mathrm{PO}_{4}^{-}, \mathrm{Ce}^{+3}, \mathbf{W}^{+6}, \mathrm{Mg}^{+2}, \\
\mathrm{SO}_{4}^{-2}, \mathbf{B O}_{3}^{-3}\end{array}$} & \multirow[t]{2}{*}{ (IV) } & 50 & 104.0 \\
\hline & & 100 & 108.8 \\
\hline \multirow{2}{*}{$\begin{array}{l}\mathrm{Ni}^{+2}, \mathrm{Mg}^{+2}, \mathbf{W}^{+6}, \mathrm{Ca}^{+2} \\
\mathrm{~S}_{2} \mathrm{O}_{3}^{-2}, \mathrm{Br}^{-}\end{array}$} & \multirow[t]{2}{*}{$(\mathrm{V})$} & 50 & 103.1 \\
\hline & & 100 & 106.3 \\
\hline
\end{tabular}

Other composite mixtures were tried but results were unsuccessful. It can be observed Table (9) that the method gives a successful recovery of tellurium (IV), and applicable for all cases except for mixture (III)

\section{Determination of Tellurium (IV) in sea water}

The following Table shows the results obtained for the determination of Te (IV) in sea water which was prepared in the laboratory (Henriksen, 1965).

Table 10: Determination of Te (IV) in sea water sample

\begin{tabular}{|l|l|l|}
\hline $\begin{array}{l}\text { Sample of sea water } \\
(\mathbf{m L})\end{array}$ & Te (IV) added, $\boldsymbol{\mu g}$ & Recovery* \% \\
\hline 0.5 & 25 & 96.3 \\
\cline { 2 - 3 } & 40 & 100.2 \\
\cline { 2 - 3 } & 50 & 98.5 \\
\hline \multirow{3}{*}{1.0} & 25 & 95.1 \\
\cline { 2 - 3 } & 40 & 102.9 \\
\cline { 2 - 3 } & 50 & 93.31 \\
\hline \multirow{3}{*}{1.5} & 25 & 89.7 \\
\cline { 2 - 3 } & 40 & 103.2 \\
\cline { 2 - 3 } & 50 & 90.2 \\
\hline
\end{tabular}

*Average of three determinations. 
Sadallah T. Sulaiman et al.,

The results in Table (10) were satisfactory to some extent and recovery ranged from 89.7 to $103.2 \%$.

\section{Comparison of the method}

Table (11) shows the comparison between the analytical variables of the present method with another method (Marczenko, 2000).

Table 11: Comparison of the method

\begin{tabular}{|l|l|l|}
\hline Analytical parameters & Present method & $\begin{array}{l}\text { Literature method } \\
\text { (Marczenko, 2000) }\end{array}$ \\
\hline Reagent & Chrome azurol S & bismuthiol (II) \\
\hline$\lambda_{\max }(\mathrm{nm})$ & 525 & 330 \\
\hline Surfactant used & $\mathrm{CPC}$ & ---------------------- \\
\hline Beer s Law range $(\mathrm{ppm})$ & $0.2-2$ & --------------------- \\
\hline $\mathrm{pH}$ & 10 & 8 \\
\hline Sandell's index $\left(\mu \mathrm{gg} \cdot \mathrm{cm}^{-2}\right)$ & $5.104 \times 10^{-3}$ & $1.595 \times 10^{-2}$ \\
\hline Nature of Complex & $1: 2$ & $1: 4$ \\
\hline Molar absorptivity $\left(1 . \mathrm{mol}^{-1} . \mathrm{cm}^{-1}\right)$ & $2.5 \times 10^{4}$ & $8 \times 10^{3}$ \\
\hline $\mathrm{K},\left(\mathrm{M}^{-2}\right)$ & $3.6 \times 10^{10}$ & ----------------- \\
\hline
\end{tabular}

The present method differs from the literature method in two main things:

(a) The introduction of CPC surfactant, gives more sensitive reaction with Te (IV) ion than the literature method.

(b) The detailed optimization of experimental conditions has not been established yet.

\section{REFERENCES}

Fluka, Riedel-Dehean, Sigma-Aldrich. (2007-2008). "Labrotary Chemical, and Analytical Reagents". 526 p.

Hargis, L.G. (1988). "Analytical Chemistry Principles and Techniques". PrenticHall International Ltd., London, pp. 424-426.

Henriksen, A. (1965). An automatic method for determining nitrate and nitrite in fresh and saline waters. Analyst. 90, 38-88

Hui-Ming, L.; Shi-Yang, C.; Pin-Husan, C.; Suh-Jen, J.T. (2002). Determination of bismuth, selenium and tellurium in nicke alloys and pure copper by flow-injection hydride generation atomic absorption spectrometry-with ascorbic acid prereduction and cupferron chelation-extraction. Anal. Chim. Acta, 459, 161-168.

Ken, Z. (2010). The impact of tellurium supply on cadmium telluride photovoltaics. Science, 328(5979), 699-701.

Kumar, A.; Sharma, P.; Chandel, L.K. (2008). Synergistic extraction and spectrophotometric determination of palladium (II), iron (III), and tellurium (IV) at trace level by newly synthesized p-[4-(3,5-dimethylisoxazolyl) azophenylazo] calyx (4). J. Incl. Phenom. Macrocycl. Chem. 61, 335-342.

Maoyang, Xi.; Rui, 1.; Peng, Wu.; Kailai, Xu.; Xiandeng, H.; Yi, L. (2010). Atomic absorption spectrometric determination of trace tellurium after hydride trapping on platinum-coated tungsten coil. Microchem. J., 95(2), 320-325. 
Marczenko, Z.; Balcerzak, M. (2000). "Analytical Spectroscopy Library Separation, Preconcentration and Spectrophotometry in Inorganic Analysis". EllisHorwood Ltd, Chichester, Elsevier (CD- ROM). pp. 415-419.

Mushran, S.P.; Prakash, O.; Sanyal, P. (2004). Spectrophotometric study of Co (II)- chrome azurol s chelate. J. Fur. Prak. Chem., 383 ( 4), 125-129.

Najafi, N.M.; Tavakoli, H.; Alizadeh, R.; Seidi, S. (2010). Speciation and determination of ultra trace amounts of inorganic tellurium in environmental water samples by dispersive liquid-liquid microextraction and electrothermal atomic absorption spectrometry. Anal. Chim. Acta, 670, (1-2), 1823.

Perrin, D.D.; Dempsey, B. (1974). "Buffers for $\mathrm{pH}$ and Metal Ion Control". Chapman and Halld, London, 47, $152 \mathrm{p}$.

Poledniok, J.; Buhl, F. (2006). Application of chrome azurol $\mathrm{s}$ and benzyldodecyldimethylammonium bromide for determination of indium in zinc and its compounds. Chem. Anal., 51(4), 631.

Starczewska, B. (2004). Spectrophotometric determtnation of vanadium (IV) by ternary complexes of chrome azurol S with imipramine and chlorprothixene. J. Trace and Microprobe Techn., 20(3), 377-384.

Valcarcel, M. (2000). " Principles of Analytical Chemistry". Spring-Verlag, Berlin, 68 p.

Mediawlki, (2012). Wikipedia, in encyclopedia, at 09: 25, pp.1-5.

Whinnie, W.R.Mc. (1995). "Tellurium Inorganic Chemistry Encyclopedia of Inorganic Chemistry". Ed. R. Bruce King (1994). Jon Wiley and Sons. 